\section{Euricse}

European Research Institute

Mitja Stefancic

ISSN 2281-8235 Working Paper n. 99|17 Silvio Goglio

Ivana Catturani

\title{
Democratic Governance Mechanisms in Cooperative Banks: A Reassessment
}

Please cite this paper as:

Stefancic, M., Goglio, S. \& Catturani, I. (2017), Democratic Governance Mechanisms in Cooperative Banks: A Reassessment, Euricse Working Papers, $99 \mid 17$. 


\title{
Democratic Governance Mechanisms in Cooperative Banks: \\ A Reassessment
}

\author{
Mitja Stefancic* Silvio Goglio * Ivana Catturani»
}

\begin{abstract}
The governance of cooperative banks is arguably so distinctive that it cannot be properly captured by standard economic models. One of the problems that arises in the assessment of the assumed democratic governance in such banks refers to the members' commitment to the banks. This paper considers the fact that it is not always clear whether cooperative banks' members have the proper incentives to actively participate in making decisions that relate to bank strategies and policies. To shed light on this problem, this paper provides an improved framework of governance based on some seminal concepts by Albert O. Hirschman (1970), such as voice, exit and loyalty. Given the challenges that cooperative banks are currently facing, the arguments discussed in this paper should help illuminate the kind of reforms that such banks are expected to pursue in the coming years. Their governance model needs to be updated in practice to retain its specific features; otherwise, it may end up mirroring that of standard forprofit banks.
\end{abstract}

\section{Keywords}

Cooperative banks; Democratic governance; Commitment of members; Albert O. Hirschman

\section{JEL codes}

D71; D72; G21; G3

\footnotetext{
- Euricse, Italy (corresponding author). Email: mitja.s@ hotmail.it

- University of Trento and Euricse. Email: silvio.goglio@unitn.it

University of Trento and Euricse. Email: ivana.catturani@unitn.it
} 


\section{Introduction (aims and structure)}

Recent research shows that the governance of cooperative banks is distinctive; as such, it cannot be adequately captured by using standard economic models and assumptions (Borgström, 2013; Jones and Kalmi, 2015; Jones, Jussila and Kalmi, 2016; Paredes-Frigolett, Nachar-Calderón and Marcuello, 2016). At the same time, such governance is subject to change. Cooperative banks need to update their governance mechanisms in order to respond to challenges and slacks and in the same way, to avoid losing their specific features. Existing accounts are still incomplete since they are missing important points - several of which are addressed in this paper. To achieve this goal, this paper refers to the seminal discussions on democracy, as well as to some valuable insights offered by economists, such as Albert O. Hirschman (1970).

The reason for developing a novel framework is twofold. On one hand, several authors stress the importance of democratic governance in cooperative banks as opposed to that based on personal investment (namely, number of shares) in standard commercial banks, with rather limited democracy, in this sense. On the other hand, a cooperative model of governance is not free from flaws, either. Critical approaches to a cooperative model of governance tend to stress its side effects, for instance, low incentives for cooperative banks' members to monitor top managers, members' lack of information about policies adopted by top managers, inability to make proper and timely decisions due to dispersed ownership and finally, the so-called groupthink problem (Janis, 1982; Goglio and Catturani, 2017).

Hence, there is the need to reconsider the concept of democracy in banking and more generally, in firms - with all its merits and benefits, along with some shortcomings. Some sort of democracy existing in the governance of private, commercial and more generally, profitoriented banks cannot be denied since votes are equally distributed based on shares. In other words, the "one head, one vote" principle is representative of membership, whereas the "one share, one vote" mechanism is illustrative of the investment and the risk assumed.

Members of cooperative banks may prefer such banks because in principle, securing a certain degree of participation in decision-making processes adds to the appealing idea of social justice. Nevertheless, empirical evidence suggests that large cooperative banks often depart from the original cooperative model (Alexopoulos, Catturani and Goglio, 2013) and adopt models of governance that closely mirror those of standard commercial banks. The planned transformation of some of the largest Italian cooperative banks (banche popolari) into jointstock banks and the demutualisation of the building societies in the United Kingdom (UK) are examples of this transition towards a commercial model of banking. Additionally, while the democratic model of cooperative banking proved to be quite successful in the past, its specificities are becoming increasingly difficult to maintain due to banks' growth in size and the heterogeneity of their members, on one hand, and stringent banking regulations and vigilance requirements, on the other hand. 
To better investigate the pros and cons of the general participative model of cooperative banking and to assess its degree of democracy, two underlying assumptions are required. First, different meanings are attached to the concept of democracy, depending on whether the framework is political or economic, for example. Different frameworks also assume various types of efficiency of democratic processes/outcomes. Second, although democracy may sound appealing in principle, it may be less effective or efficient in practice, specifically, in the decision-making process (particularly in adverse periods) and the selection mechanisms of administrators and top managers, unless some prerequisites are matched. Therefore, democratic control and governance can indeed pave the way to adverse selection; candidates with lower skills and managerial capabilities can be chosen over better candidates (e.g., over the optimal bank leader) to manage the bank. Furthermore, similar to the case in politics, democratic elections in banks can be influenced by the candidates' strategies and related propaganda ${ }^{1}$. Democratic elections are also not necessarily free from lobbying or potential fraud.

The aim of this analysis of cooperative ownership and voting in banks is to provide substantial arguments for a much needed improvement of such a model. Without essential improvements, the governance of cooperative banks may start to gradually lose its specificities, thus more closely approximating standard for-profit bank models ${ }^{2}$.

This paper is structured as follows. Section 2 presents the main features of governance of different types of banks. Section 3 provides a concise review of the literature on democratic governance, useful for developing the subsequent discussion. Section 4 sets the conceptual framework by distinguishing among the different meanings of democracy - depending on the context in which it is used. Section 5 provides a methodological account of the main elements of democratic governance by drawing on Hirschman's (1970) work, particularly with reference to the decline of firms and organisations. Section 6 provides an economic scheme of the discontent of cooperative banks' members, and Section 7 concludes the paper.

\section{Main features of governance of different types of banks}

From the outset, it is sensible to ask whether the constant reference to democracy made by the cooperative system and elaborated on by the cooperative movement itself is supported by evidence or primarily represents an ideological argument, useful for promotional purposes (such as to stress market differentiation). The argument rests on the "one head, one vote" principle. The question therefore is whether this principle promotes true democratic management/governance, even if not clearly defined, or represents a system of governance in which strategic decisions pertain to restricted groups.

\footnotetext{
${ }^{1}$ As observed by Callander (2008), even interactions among candidates with different motivations can influence voting processes and policy outcomes.

${ }^{2}$ Some scholars have recently shown awareness of this point (for a discussion on the transition of German cooperative banks, see, for instance, Jovanović, Arnold and Voigt, 2017).
} 
To properly assess the kinds of democratic governance mechanisms employed in different types of banks, it is useful to start by focusing the discussion on their fundamental characteristics. For simplicity reasons, the discussion concentrates on two main typologies - joint-stock (mainstream) and cooperative banks. Both bank groups are owned privately and compete on the market. These banks are therefore quite different from public banks, usually owned by the state. Both joint-stock and cooperative banks are indeed for-profit banks; the main differences lie in the distribution and use of profits.

To begin with, in joint-stock banks, decision-making power (or control over administrators and top managers) is proportional to the investment of each shareholder, as exemplified by the number of shares. The democratic aspect of shareholder banks is based on the "one share, one vote" principle. Furthermore, each bank usually has a single and centralised board, operating top-down through an appointed chief executive officer with wide latitude to define the company's operating strategies, policies and structures from the centre (Oliver Wyman, 2014).

In contrast, cooperative banks need to refer to their members when setting their policies. Specifically, disciplining mechanisms in cooperative banks are in principle the result of decisions made by their members - the bank owners. One of the problems that arises in the assessment of the efficiency of democratic governance in such banks involves the members' commitment to the banks. It is not always clear whether such members have the proper incentives to actively participate in making decisions regarding bank strategies and policies, and this issue has been largely neglected in the economic literature (Ferri, Kalmi and Kerola, 2015).

A second important aspect is that of achieving the right balance among the different aims pursued by the members of a cooperative bank. Arguably, with the growing complexity of cooperative banks and their operations, it is now much more difficult to bring together diverse interests of their members than it was in the past. As correctly observed by Groeneveld (2015), while membership in a cooperative bank was originally a condition for a customer to obtain a loan from that bank, matters are currently quite different. "[T] he average member to customer ratio [in European cooperative banks] now stands at 30 per cent, which implies that a large majority of customers are not members of a cooperative bank and that customers are not automatically members" (Groeneveld, 2015: 8). Moreover, some members are mainly depositors, with quite different interests from the borrowers. In other words, the larger the dimensions of the bank are, the less homogeneous/aligned the interests of its stakeholders become.

The above-mentioned observations help shed light on the kind of transformations affecting cooperative banks, which also influences their assumed democratic governance. The question is whether such a model of governance is really efficient and democratic. The transformations that have occurred over time seem to point out that democracy has become somewhat more limited than in the past. It is also worth mentioning that cooperative banks differ among themselves and could be classified according to their histories, dimensions and countries or 
even the regions where they operate (Ayadi et al., 2010). Nonetheless, this paper suggests keeping the distinction simple by distinguishing between "popular" banks (e.g., the Volksbanken in Germany, banche popolari in Italy, banques populaires in France) and local mutual banks (Raiffeisen banks, banche di credito cooperativo, etc.).

Currently, these two main business models, classified as forming a single "cooperative" group in the past, are increasingly departing from a common model. They seem to have taken two distinct development paths in their aim to provide adequate responses to developmental trends at local levels and to the issues related to the financial crisis. A suitable case study is provided by the Italian banking system, where large popular banks have adopted the form of joint-stock banks, whereas local cooperative banks continue to operate according to cooperative principles by preserving their original business model and ownership specifics. Indeed, there is a clear demutualisation trend in large cooperative banks, particularly in the banche popolari - "the system whereby shareholders are entitled to a single vote regardless of the size of their stake will be abandoned" (The Economist, 2015). On the other hand, local cooperative banks have to join a cooperative banking group despite retaining their banking licence for operating on the market; alternatively, each bank has to be transformed into a joint-stock company to operate independently.

\section{Democratic governance: theoretical review}

Any attempt to effectively discuss the efficiency of the democratic governance of cooperative banks is destined to lack depth unless some theories on democratic voting, the quality of selection mechanisms in democratic systems and governance models in enterprises (including banks) are taken into account. For this reason, this section provides a theoretical overview of the most prominent aspects emerging from scholarly research. The relevant questions are as follows: What does extant research inform readers about models of democratic voting and democratic governance? Can the governance of cooperative banks be assessed and framed adequately according to extant theoretical insights? What types of models are most useful for developing a general economic model of democratic governance in banking?

\subsection{Democratic voting mechanisms}

Some models directly focus on democratic governance mechanisms and democratic voting. They appear useful for framing the present discussion.

Besley and Coate (1997) conceptualise a pure form of representative democracy with reference to a theoretical framework in which citizens who care about policy outcomes elect a candidate by means of assignation of votes. The successful candidate then chooses a policy. Besley and Coate's model suggests that representative democracy may not always produce efficient solutions if citizens differ in their policy-making abilities. In practice, citizens may select 
representatives with lower skills, simply for demonstrating the ability to better represent their views.

In contrast, Klingelhofer (2010) attempts to improve the "citizen candidate framework" advanced by Besley and Coate (1997 and 2001) by focusing on both ideological aspects and lobbying related to democratic election mechanisms. In developing a model with ideological parties, the author shows that the existence of interest groups often influences voting results for example, their influence makes the median voter better off. In Klingelhofer's model, lobbying does influence policy as lobbies are basically able to influence or even change the choice sets of voters. From this point of view, democratic voting is subject to ideological manipulation.

Based on psychologists Kruger and Dunning's (1999) evidence that people often make unfortunate choices in their selection processes, Nagel (2010) argues that democratic elections can often result in the selection of rather mediocre political leaders. Thus, he suggests that the main advantage of democratic elections seems limited to preventing lower-than-average candidates from becoming leaders. Ideal types of leaders are almost never elected by voters in a democratic process; accordingly, their election is an exception rather than the rule.

In his discussion on the models of perfect competition and pure democracy, Frey (1970) finds that in terms of income distribution, pure democracy seems quite efficient because in theory, it starts from an equal distribution of political resources, such as votes. Nevertheless, Frey concludes that in practice, this is not always the case; "in reality political resources are not distributed equally among citizens... one's vote is strongly correlated with one's economic position. The degree of information, of interest, and of actual political participation are clearly a function of income (and wealth)" (Frey, 1970: 752). Arguably, the same kind of inequalities can be found in cooperative enterprises, including cooperative banks - though to a much lower extent.

\subsection{Democratic corporate governance}

Osterloh, Frey and Zeitoun (2011) argue that dominant corporate governance paradigms have failed to prevent opportunism - one of the main causes of the 2007/2008 global financial crisis. They define corporate governance as an institution that intends to overcome social dilemmas. They find that to increase cooperation, it is essential that the individuals at the top levels of the hierarchy (directors and managers) be endowed with "prosocial preferences" to contribute to collective goods. Furthermore, they observe that employee participation in decision making and control is beneficial to corporate organisations.

Groeneveld (2015: 12) explains that typically, cooperative banks are "governed by their members (client-owners) with direct or indirect member representation at all layers of governance. Local members or member constituencies elect Non-Executive Board members, or in some instances called local supervisors, who monitor and control local/regional cooperative banks". 
The European Association of Co-operative Banks (EACB) stresses the positive outcomes of using democratic assets in the governance of cooperative banks. At the core of such a democratic model of voting is the general assembly, which allows the members' democratic participation in bank governance. Among other things, the "democratic participation of the members in the general assembly efficiently maintains the balance of power among the members as owners and the directors of cooperative banks" (EACB, 2006: 6). Moreover, votes are counted according to the "one vote per person" rule, which, from a theoretical perspective, could suffice to secure an adequate degree of social equality among the bank members. Is this really the case?

Focusing on the complex governance of cooperative banks, Alexopoulos, Catturani and Goglio (2013) distinguish among different types of control over top managers in such banks. Along with incentive schemes for managers, voting during general assemblies is a mechanism for direct control over top managers. However, according to the authors, this does not provide much information about bank members' degree of participation in general assemblies. Additionally, one of the main issues originates from the problem of groupthink (a suboptimal decisionmaking outcome resulting from the group desire for conformity), which may ultimately result in poor investment strategies by cooperative banks - particularly the larger ones.

Another issue that needs to be further discussed is the relation between control and ownership structure; this topic is particularly relevant to cooperative banks as their governance is based on a cooperative model of ownership. Focusing on Austrian cooperative banks, Gorton and Schmid (1999) find that bank performance declines as the number of members increases due to greater separation of ownership and control. Particularly, the greater the separation between ownership and control, the greater the agency costs, resulting in the low performance of such banks. Other researchers have mentioned this problem in terms of costs resulting from dispersed ownership of cooperative banks (e.g., Stefancic, 2015).

\subsection{Democratic governance in practice}

Sarcinelli (1997) argues that cooperative banks often appear to be better organised than banks in the form of joint-stock companies. In terms of organisational efficiency, cooperative banks sometimes seem to outperform commercial banks. "[A] key strength of the cooperative banks and mutual banks is certainly their homogeneous shareholder base and a close fiduciary relationship that ordinarily makes for accurate ex ante selection of managers and constant monitoring of their action. Perhaps this is why relatively small cooperatives among shareholders who are also 'clients' have managed to outperform large profit-oriented corporations" (ibid.: 262). Recent investigations have confirmed this result (see, for instance, the case of the German cooperative banks, discussed by Jovanović, Arnold and Voigt, 2017).

However, the governance of cooperative banks has recently attracted major criticism. For example, D'Amato and Gallo (2017) empirically show the relation between low board turnover and board ineffectiveness. This result holds particularly true for small cooperative banks. One 
of the most interesting findings from this study is that in such types of banks, board members often have the power to favour friends or even "members of the coalition of owners who elected them" (ibid.: 97). Otherwise stated, board members in cooperative banks can be tempted to deviate from policies that would be "optimal" for the entire bank (cooperative owners and the local community), preferring others that are "optimal" only for a few members.

In a sense, the problems of opportunism and suboptimal policy outcomes seem to match another issue that may often be present in cooperative banks, that is, the problem of groupthink. In fact, "the longer the directors have been on the board, the more plausible [it] is that they share a common view and possible that they agree most of the time on their decisions" (Alexopoulos, Catturani and Goglio, 2013: 406). This casts some doubts on the fiduciary relationships that are often viewed positively when applied to cooperative banking (see, for instance, Sarcinelli, 1997). However, what if trust does not solve the problem of groupthink, thus preventing effective monitoring of bank managers? What if it leads to distorted policies that do not match proper welfare - those that can be shared by all cooperative banks' members and stakeholders at large?

\section{Democracy: political and economic dimensions}

The apparently straightforward concept of democracy can be potentially misleading unless properly framed and discussed. On one hand, the definition of democracy depends on how the $\delta \eta \dot{\mu o \varsigma}$ (demos, meaning constituency) is defined. On the other hand, democracy can be based on direct participation in decision making (direct democracy) or on the election of representatives in charge of making the decisions (representative democracy). However, with the increase in dimension, direct democracy is no longer viable ${ }^{3}$. Therefore, in the following subsections, democracy is intended as representative, and the focus is on the definition of demos in political or economic terms.

\subsection{Political democracy}

In contemporary public discourse, the term "democracy" often refers to a political system based on the separation of power - one in which citizens have the right to vote to set their political choices and preferences and the ability to exert an adequate degree of control over political power. Democracy is in practice often based on antagonism, which means that it is conflictual in its very essence; it needs to constantly solve internal issues (Manin, 1987; Mouffe, 2000). Despite this fact, unless citizens actively participate in elections, show thorough interest in the outcomes and are well informed about their political alternatives, democratic systems are at risk

\footnotetext{
${ }^{3}$ The fact that the essential conditions of democracy are challenged by factors such as dimensional growth is first noted by Montesquieu in De l'esprit des lois (1748). Similarly, Kelsen (1920) argues that in a representative system, the democratic element is substantially diluted and weakened.
} 
of failure (Sartori, 2008). It should be noted that democratic rights originate from citizenship, whereas in banks, they originate from ownership and investment. This distinction should be kept in mind throughout this paper.

According to John Stuart Mill (2011 [1861]), those who make decisions need to be competent, wise and objective with respect to a set of different types of interests of stakeholders. Referring to Mill, Dahl (1989) suggests that from an organisational perspective, democracy tends to adequately secure the protection of fundamental individual rights/interests. This is only viable if individuals possess the strength and the tools to protect their own rights/interests. Since such interests are usually diversified and do not necessarily match each other, the outcome is a game of plural organised interests in competition. Therefore, a solution (i.e., governance) is really democratic when none of these interests is left unaddressed or unprotected. The question then is not just whether cooperatives (particularly when they grow above a threshold) can better achieve this optimal result (democratic governance) compared with other forms of organisation but also whether in pursuing this goal, they may end up facing the problem of inefficiency - to the point that their survival on the market or their capacity to offer a public good could be questioned.

Therefore, for Dahl, perfect democracy is difficult to achieve in practice. He identifies a set of prerequisites for a well-functioning democracy, such as citizens' effective participation in a democratic process, voting equality, proper understanding of policies and their potential outcomes, control over political agendas and inclusiveness (equality must be extended to all citizens in the state). As a form of government, democracy can pave the way for a number of desirable outcomes, such as self-determination, the protection of personal interests, political equality and prosperity (Dahl, 2000). In this regard, the principle of arriving at a decision through a majority vote is democratic if - and only if - the preferences expressed by the voters are determined freely. This happens when there is no significant conditioning and when the information is both accessible and transparent. There should also be a thorough public discussion on the main issues/arguments at stake. Alternatively, there may be incomplete information or not well-defined preferences in the beginning, yet the deliberative process needs to gradually solve these internal contradictions (Manin, 1987).

Furthermore, the decisional autonomy of managers should be mentioned, that is, their behaviour may often divert an organisation from its objectives (agency problem) - as already discussed by Rousseau (1762) in his Du contrat social. This issue is particularly relevant for assessing efficiency in cooperative governance. With reference to the figure of the "magistrates", Rousseau (1762) suggests three kinds of behaviours/motivations on which their actions are based: an individualistic approach seeking personal advantage and benefits, a corporate approach aiming to secure advantages for the magistrates and finally, a general approach intending to produce optimal social outcomes (which ought to be the primary motivation of the magistrates). Similarly, Michels (1910) argues that those who are closely connected to an organisation and draw prestige from it are willing to fulfil the conditions for its consolidation; 
however, this may clash with or prevail on the original goals on which the organisation has been founded. According to Michels, the "iron law of oligarchy" states that all forms of organisation, regardless of how democratic they may be at the start, will eventually and inevitably develop oligarchic tendencies, thus making true democracy impossible to achieve in practice ${ }^{4}$. Moreover, the mass of voters is influenced by those with more tactical skills, knowledge and power (persuasion tools), hence the possibility for small social groups to become influential or even occupy a dominant position over others. After all, Plato in his Menexenus already convincingly states that a democracy approximates an aristocracy (or perhaps, only an oligarchy), with the approval of the mass of voters. Arguably, all this adds to the problem of groupthink.

Whether democracy is a prerequisite for a prosperous economic system is hence open to debate. According to Galli (2011), democracy comprises several social aspects, including private economic interests, among others. Some liberal economists suggest that democracy could not exist without capitalism, as if the political order would heavily depend on the economic system and the system of production (see Usher, 1981). However, particularly after the global financial crisis, there is awareness that matters are not so straightforward.

\subsection{Economic democracy}

Economic democracy can be viewed as a potential outcome of evolution, starting from either capitalism or socialism. In such a system, most of the economic enterprises are democratic worker-owned firms (Dahl, 1985; Ellerman, 1990). Generally, there is substantial agreement that such a system is based on three pillars: the market, workers' self-management (or an approximation of it) and social control over investment (Malleson, 2014).

From this point of view, the concept of democracy has mainly economic implications; for example, investment is under substantial social control (Krätke, 2008). However, it should be noted that economic democracy does not require the abolition of private property; other types of reforms and contractual changes are more essential for its establishment and subsequent consolidation. According to Ellerman (1990), democracy and private property of firms do not essentially clash with each other. The fact that democratically managed firms owned by employees can be indeed competitive on the market suggests that property rights can remain largely private.

\subsection{Democracy within enterprises and banks}

The above-mentioned arguments pave the way for an appraisal of cooperative firms. If political democracy is based on citizenship, then democracy in these enterprises is based on cooperative ownership. Property rights provide the right to vote, but voting mechanisms in cooperative firms differ substantially from those that are typical of shareholder firms. Indeed, a distinctive feature of cooperative firms is that they are organised according to the "one person, one vote"

\footnotetext{
4 “Democracy means organization, organization means oligarchy, hence democracy means oligarchy".
} 
principle, often viewed as an example of equal voting rights within firms. Some scholars define cooperative firms as "self-governing economic enterprises" as they are controlled democratically. Otherwise stated, the "enterprise's citizens" determine how the revenues generated by the firm are to be allocated (Dahl, 1987).

A characteristic feature of these enterprises is membership. "[T]he members themselves would decide on the principles according to which wages, salaries, and surplus were to be distributed among members. Their choice of internal distributive principles would depend on factors that are very far from predictable, including their implicit and explicit beliefs about fairness, which in turn would be influenced by tradition, the prevailing culture, ideology, religion and the like" (Dahl, 1987: 197).

The same principle should apply to cooperative banks, formally owned by members with the right to participate in their decision-making processes. In contrast to the position of Malleson (2014), who advocates for publicly owned banks, it is suggested in the present paper that this specific bank typology (rather than public banks) fits well in economic democracy. However, it should not be forgotten that cooperative banks constitute a specific type of cooperatives; they may better approximate the standard definition of banks than the definition of a typical cooperative enterprise.

To sum up, economic democracy is closer to political democracy when the workers are the constituency. In this sense, since being employed is a precondition to joining the constituency, similar to citizenship, the two types of democracy are equivalent. Citizenship or work makes a person a member of the demos. In a cooperative enterprise, the requirement for membership is to belong to the tight community (the firm). Matters are different in the case of cooperative banks, since the assessment of the constituency derives from being members of a loose community of consumers and from the payment of a fee. The difficulties in classifying such constituency become even more pronounced with the increase in both the size of the bank and the heterogeneity of the membership.

\section{Methodology}

The empirical analysis of these issues is a demanding task as data on cooperative banks are not easy to access at a European level. It is also difficult to empirically bring together and then test cooperative banks of different types, such as standard local cooperative banks, credit unions, building societies that operate in the UK or other types of mutual banks operated by local communities or cooperatives.

The analysis is kept simple since the purpose of this paper is to discuss the above issues in layman's terms rather than to provide definitive conclusions on such complex issues. At present, the approach is rather descriptive and largely influenced by the theoretical framework provided by Hirschman in his treatise Exit, Voice, and Loyalty (1970). The latter sets a 
framework based on concepts such as "exit", "voice" and "loyalty", which can improve current accounts focusing on the governance of cooperative banks by allowing administrators to account for the discontent expressed by members. Drawing on Hirschman's work, it can be assumed that a bank's administrators use the loyalty of members-customers to shield themselves from the critical assessments in place due to competition mechanisms.

Despite recognising that some of Hirschman's concepts are not that easy to grasp and are subject to interpretation (Withey and Cooper, 1989; Graham and Keeley, 1992; Leck and Saunders, 1992), it can be safely assumed that too much loyalty may have counterproductive effects, such as limiting the members' willingness to monitor. On the other hand, frequent exit may drain the bank's financial and relational resources, substantially decreasing the power of "voice" (the best members may decide to exit, leaving the bank poor).

The approach advanced in this paper can be defined as a political model, in the sense of focusing on both voting mechanisms and tools to express discontent or in contrast, enhance loyalty. The focus is on the side of "voting rights", critical capabilities of members, their ability to correctly interpret bank policies and the kind of opportunities they have to provide constructive criticisms. At the same time, the framework tries to capture the notion of the bank's "efficiency", here understood as an ability to recover productivity after slacks and/or to properly overcome periods of slacks. The advantage is that this definition holds true, irrespective of the objective function pursued by the bank.

\section{An economic model of the discontent of cooperative banks' members}

Democracy allows the demos to participate in the decision-making process through elected representatives. The underlying assumption is that the constituency is interested in doing so. This section presents a novel discussion on the peculiarities of bank governance, comparing members' and shareholders' owned banks by referring to Hirschman's seminal work Exit, Voice, and Loyalty (1970). Hirschman discusses the ways of reacting to deterioration in business firms or more generally, the lack of satisfaction in organisations. He provides a set of concepts and ideas, which form a valuable framework to critically assess governance mechanisms in banks, beyond the voting rules.

\subsection{Preliminary considerations}

Hirschman's framework is meant to be generic across firms. However, it is important to specify some peculiarities of banks in general and of cooperative banks in particular to gain a better understanding of their governance mechanisms and to provide proper contextualisation of relevant problems.

First, banks mediate between the demand and the supply sides of credit and provide financial services; they never manufacture goods to be consumed. This has an effect on how discontent in banks can be voiced by their customers, in contrast to customers of ordinary firms. Second, 
building trust and maintaining loyalty are more complex in financial intermediaries since customers pay for services and products whose future value is uncertain, which implies risk taking.

It should be noted how - among the banks' settings - members and shareholders differ. First, an individual becomes a member by investing a small amount of money (someone just needs to buy a share). The purchased share is not tradable, and the risk on its future value is basically negligible. Shareholders buy many shares. The higher the number of shares is, the greater the risk taken becomes and consequently, the higher the interest in the governance of the bank will be. To cite Williamson (1986), it can be argued that shareholders have strong incentives to participate in governance, while members hold weak incentives. Second, while in cooperative banks, members are both owners and clients simultaneously, in shareholder-owned banks, clients are not necessarily shareholders and vice versa.

\subsection{A governance framework for banks in a positive period}

When the banks' economic performance meets the expectations of both clients and owners (i.e., members or shareholders), the governance mechanisms are straightforward. Figure 1 offers a simple representation.

Figure 1. Democratic governance

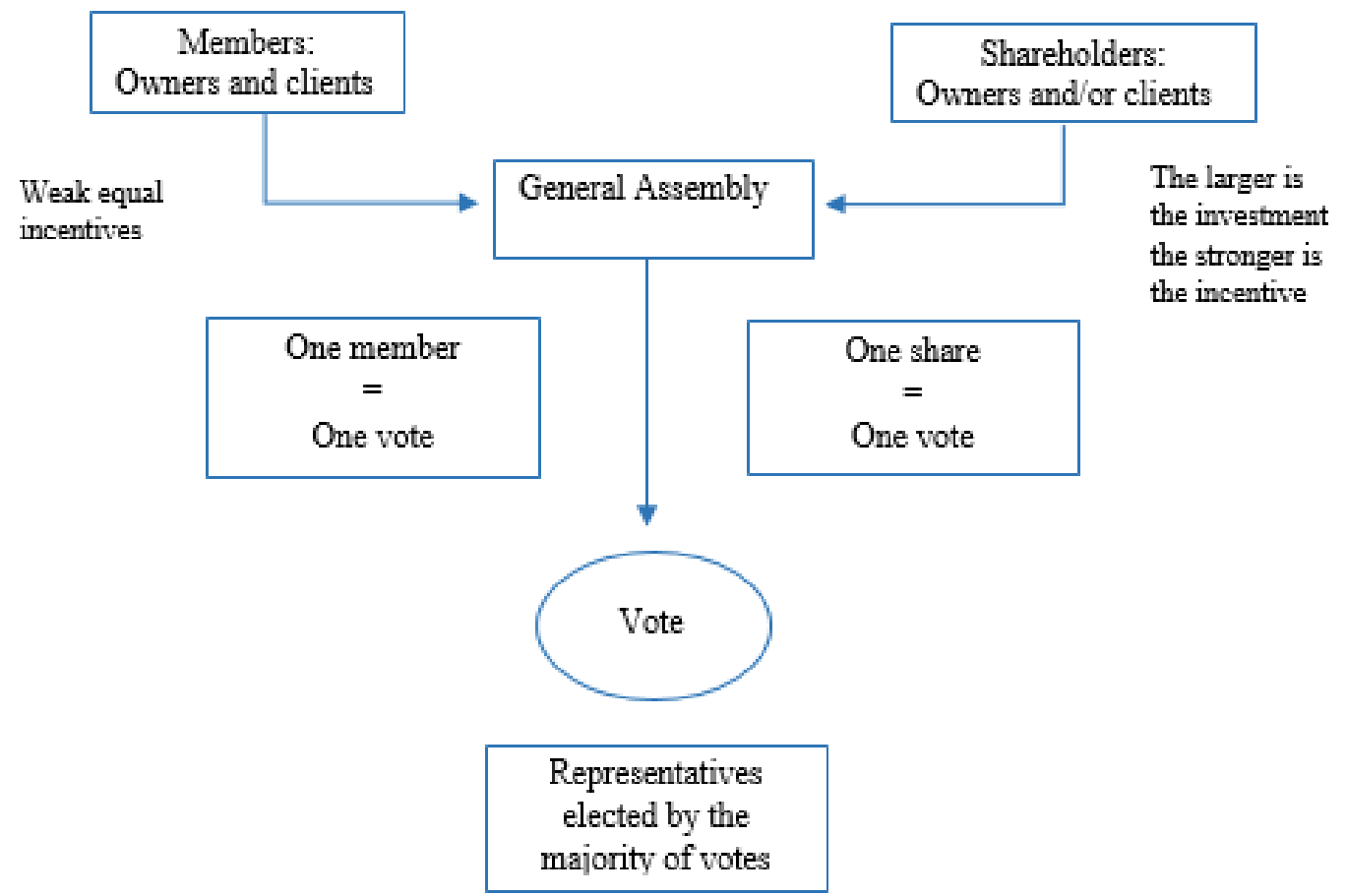


In joint-stock banks, shareholders with sufficiently large amounts of shares sit in the general assembly and vote to elect their representatives. Smaller shareholders lack the incentives to sit and vote since their decision power is negligible. They implicitly transfer their property rights to larger shareholders whose interests are prominent and whose decisions should increase the value of their shares.

In cooperative banks, members will all have the same (weak) incentives to participate in the general assembly. Their vote has equal weight and should identify those administrators among the individuals of the local community who are able to represent the various interests of the territory.

\subsection{A governance framework for banks in a negative period}

According to Hirschman's framework, when trust in firms decreases, customers have the possibility to express discontent by either switching firms or voicing their dissatisfaction.

Similarly, ordinary customers (i.e., not owners) of both joint-stock and cooperative banks can switch to other banks in case they are not pleased with the terms and conditions and services provided by the cooperative banks, its performance or general outlook. Matters become much more complex when focusing on governance issues.

In joint-stock banks, as in shareholder companies, investors can decide to be loyal and wait for better times, especially when their number of shares is relatively small. Shareholders with stronger incentives might voice their discontent and try to influence the board's decisions by expressing their views about management at the shareholders' meetings. Powerful shareholders have the ability to effectively discipline managers if the latter's strategies are not viewed as successful enough and then to align the strategies to the shareholders' expectations. Finally, they can sell their shares when the bank performance is below their expectations and their lobby pressure has no impact on the board. However, it should be observed that different from cooperative bank members, shareholders might have a strong incentive to exit the bank during positive periods as well, given by the extra profit derived from the capital gain. These shareholders' loyalty is very low, while the capital incentives are high. This case is not contemplated for cooperative bank members.

In cooperative banks, shares are usually not tradable (Ferri, Kalmi and Kerola, 2015). Instead, the most powerful tool in the hands of members is "utterance", to express their eventual dissatisfaction, concerns or disappointment in the bank. In other words, the general assembly is the place where participating members can direct their utterances to the cooperative bank managers and representatives. However, this implies an individual position grip. The problem is to clarify how often this tool is really used by cooperative banks' members when faced with adverse circumstances. Stated otherwise, how representative, trustworthy and efficient is the democratic governance in cooperative banks? 
Several practical limitations are related to the model of governance in cooperative banks, all of which can in some way restrict the efficiency of the utterances of members during the assemblies. The following are examples:

- A cooperative bank's members may be loyal to their bank and may decide to remain so even during times of distress.

- Most members may simply be unable to detect deficiencies in the bank in a timely manner (due to limited information or limited ability to monitor the top managers and administrators).

- Members may simply lack enough incentives to adequately monitor managers and administrators (limited willingness to monitor managers); weak incentives lead to not feeling the need to assess the risks faced by the bank.

The above-mentioned issues can be inferred by considering the specifics of membership on which cooperative banks are based. Nonetheless, another important observation should be made regarding the assumed democratic governance of cooperative banks, that is, they operate mainly at a local level. Operating locally, referring to local stakeholders and addressing local economic needs are all characteristic dimensions that distinguish these banks from large commercial banks, on one hand, and former cooperative banks that have been transformed into joint-stock banks, on the other hand. The constituency was originally based on the jus comunitatis. With the increase in size and in the heterogeneity of members, the jus comunitatis is no longer sufficient to explain the governance mechanism.

Arguably, the fact that cooperative bank governance mirrors the local dimension (e.g., the local culture) influences the voting mechanisms of members, particularly when the situation becomes problematic. Members who feel particularly attached to the bank (loyalty) may be unable to consider switching to another bank in times of distress. From a theoretical perspective, cooperative values may thus function as deterrents to exiting the bank. However, "exit" may not be a common option for members; incentives to withdraw their membership may be rather weak even when the cooperative bank does not perform well. Managers and administrators of cooperative banks seem quite safe from this disciplining mechanism.

An alternative is that customers switch to different banks yet retain their membership in the cooperative bank. This "half-way exit" is a fourth possibility that is not included in the original version of Hirschman's framework. The figure of the member no longer overlaps that of the client. Members as clients actually exit from the cooperative banks, while as owners, they become passive. Passive members do not sit in the general assembly, renouncing their property rights. There are various explanation for such behaviour, as follows: (i) Asking for the reimbursement of their shares will not give them any extra profits, especially in times of turmoil when only the actual value of the share can be paid back, not the entire amount with interest. (ii) It can be more acceptable from a reputational perspective, given the individual's role in the 
local community. (iii) It is easier to switch back to cooperative banks when the negative period ends (see Figure 2).

Figure 2. Democratic governance with "half-way exit" option

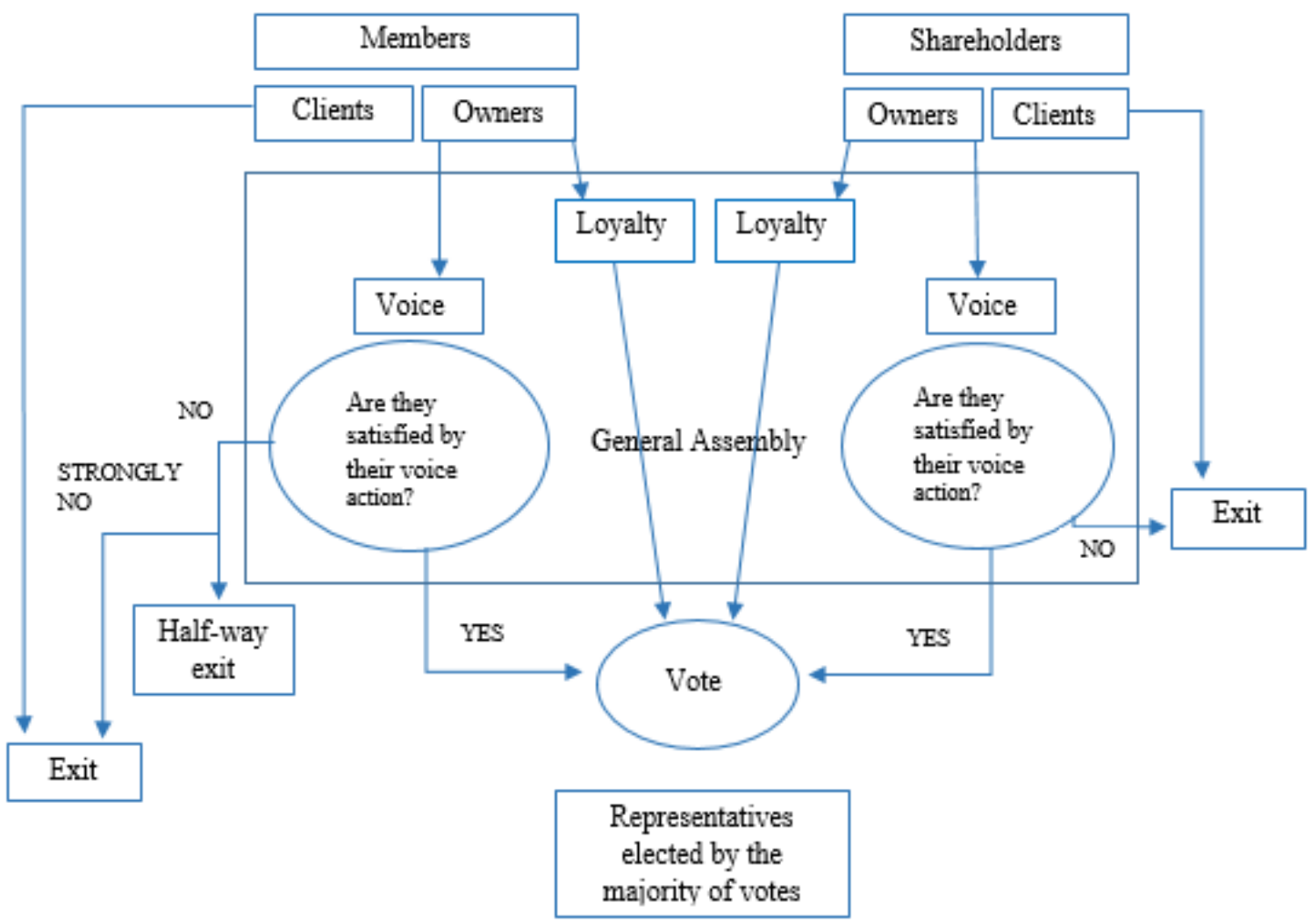

"Utterance" might be an alternative when trust in cooperative bank managers and administrators decreases for some reason. "Utterance" can be best used during the general assemblies. However, it should be asked whether utterance is sensibly used to express a member's own disappointment with the management. As suggested earlier, utterance may be limited to members who are willing to say something and to those who are able to say something meaningful (since not every member may be able to technically evaluate the bank's performance, the risks that it faces, etc.). Most members may be rather interested in negotiating their own agreements in the best possible terms with the bank and perhaps, in little more than that.

Technically, there can be no true democratic governance unless members are both able and encouraged to voice their dissatisfaction and criticisms towards the management because this is one of the few tools available for cooperative banks to obtain feedback and constructive criticism from their members, which are then useful for updating their strategies and policies. This would also be the way to provide arguments for a change originating within the bank. However, this means that members should actively participate by attending general assemblies, 
monitoring the management, seeking ways to properly evaluate the bank's performance and expressing their opinions.

Unfortunately, this task is both difficult to secure (due to the dimensional growth occurring through consolidation, mergers and development of cooperative banks) and costly for individual members in terms of the time spent to collect information and their personal reputation. Under such circumstances, keeping members participative and well informed becomes increasingly difficult. As a result, the top management of cooperative banks is reinforced - that is, safe from both (constructive) criticisms and from the discipline eventually coming from competitive mechanisms. Unless this point is properly addressed, the possibility of adequately improving the democratic governance of cooperative banks will remain remote, despite their voting rule.

\section{Relevance and discussion}

Starting from the definition of the constituency according to the types of banks, this paper has analysed the mechanisms of governance beyond its function as a mere voting tool. Comparing shareholder-owned banks with cooperative-owned banks under the framework adapted from Hirschman (1970) reveals how a cooperative bank's members can in theory choose to exit from the bank as clients and to stay as passive owners during negative economic phases. This "halfway exit" is due to two main factors. First, shares in cooperative banks are usually not tradable. Referring to the applied governance framework, this means that "a full exit" may not be a common disciplining tool in such banks. It therefore follows that options for sanctioning managers are limited in such banks. Second, given the low value of their investment as owners, it is inconvenient for cooperative banks' members to renounce their property rights (even if not claimed), from both economic and reputational perspectives.

In contrast, the most powerful tool for a cooperative bank's members to express their dissatisfaction is through utterances. To be effective, such a tool requires the members' strong commitment to monitor the bank managers and the bank's performance. This seems an ongoing problem due to the consolidation process of such banks (e.g., through mergers), at least in some European countries. Arguably, the larger the cooperative bank is, the more difficult it becomes to express discontent publicly as the general interest in the bank may decrease among members, with the growth of the latter.

Moreover, the cooperative bank members who voice their dissatisfaction or provide critical feedback during the general assemblies de facto take a critical stance towards the managers. This suggests that reputational issues are at stake - the stronger the member's role in the community, the higher the reputation at stake. In cooperative banks, a member's "weight" - in terms of his or her influence on banks' choices and on other members' bias - is proportional to his or her economic and political positions in the local community. This introduces noneconomic elements that can have detrimental effects on the bank over the long term. The recent 
failure of some Italian banche popolari operating in the Veneto region (specifically, BP Vicenza and Veneto Banca) stands as a straightforward example of this problem, which should no longer be underestimated by the regulators.

This situation has several practical implications. For instance, while loyalty and trust should be constantly fostered by cooperative banks, this effort necessarily requires the members' commitment to the bank itself. Nonetheless, loyalty should under no circumstance preclude the possibility of utterance. Utterance in cooperative banks is essential to contrast the group desire for conformity. An organisation that recognises the positive effects of utterance is able to address the problem of groupthink (Goglio and Catturani, 2017), which can in turn function as a protective mechanism for bank directors and managers, even when problems arise.

In comparing voice (utterance) with an "art constantly evolving in new directions", Hirschman (1970: 12) recognises that - as any type of valuable art - voice should be cultivated, promoted, recognised and valued accordingly. This is essentially the task of capable directors and managers serving the bank. In conclusion, this paper suggests further improvements in the framework of democratic governance in cooperative banks by distinguishing between public and private utterance. While private utterance can be used as a tool to secure ideal banking conditions in any type of bank, public utterance can be more effectively used in cooperative banks. This paper's authors should be able to address this topic in future research.

\section{References}

Alexopoulos, Y., Catturani, I. \& Goglio, S. (2013). Searching for a Model of Governance in Cooperative Banking. In: J. Brazda, M. Dellinger \& D. Rössl (Eds.), Genossenschaften im Fokus einer neuen Wirtschaftspolitik - Bericht der XVII. Internationalen Genossenschaftswissenschaftlichen Tagung (IGT) 2012 in Wien. Berlin et al.: LIT Verlag, pp. 707-731.

Ayadi, R., Llewellyn, D.T., Schmidt, R.H., Arbak, E. \& De Groen, W.P. (2010). Investigating Diversity in the Banking Sector in Europe: Key Developments, Performance and Role of Cooperative Banks. Brussels: CEPS.

Besley, T. \& Coate, S. (1997). An Economic Model of Representative Democracy, The Quarterly Journal of Economics, 112(1): 85-114.

Besley, T. \& Coate, S. (2001). Lobbying and welfare in a representative democracy, Review of Economic Studies, 68(1): 67-82.

Borgström, M. (2013). Effective co-operative governance: A practicioner's perspective, Journal of Cooperative Organization and Management, 1: 49-50.

Callander, S. (2008). Political Motivations, The Review of Economic Studies, 75(3): 671-697.

Dahl, R.A. (1985). Preface to Economic Democracy. Berkley: University of California Press.

Dahl, R.A. (1987). Sketches for a Democratic Utopia, Scandinavian Political Studies, 10(3): 195-206. 
Dahl, R.A. (1989). Democracy and Its Critics. New Haven: Yale University Press.

Dahl, R.A. (2000). On Democracy. New Haven: Yale University Press.

D’Amato, A. \& Gallo, A. (2017). Does Bank Institutional Setting Affect Board Effectiveness? Evidence from Cooperative and Joint-stock Banks, Corporate Governance: An International Review, 25(2): 78-99.

EACB (2006). Corporate Governance Principles in Co-operative Banks. Brussels: European Association of Co-operative Banks.

Ellerman, D.P. (1990). The Democratic Worker-Owned Firm: A New Model for the East and the West. London: Unwin Hyman.

Ferri, G., Kalmi, P. \& Kerola, E. (2015). Organizational Structure and Performance in European Banks: A Reassessment. In: A. Kauhanen (Ed.), Advances in the Economic Analysis of Participatory and Labor-Managed Firms (Volume 16). Bingley: Emerald, pp. 109-141.

Frey, B.S. (1970). Models of Perfect Competition and Pure Democracy, Kyklos, 23(4): 736-755.

Galli, C. (2011). Il disagio della democrazia. Torino: Einaudi.

Goglio, S. \& Catturani, I. (2017). La governance delle banche di credito cooperativo. Roma: ECRA.

Gorton, G. \& Schmid, F. (1999). Corporate governance, ownership dispersion and efficiency: Empirical evidence from Austrian cooperative banking, Journal of Corporate Finance, 5: 119-140.

Graham, J.W. \& Keeley, M. (1992). Hirschman's loyalty construct, Employee Responsibilities and Rights Journal, 5(3): 191-200.

Groeneveld, H. (2015). Governance of European Cooperative Banks: Overview, Issues and Recommendations, TIAS Working paper September 2015.

Hirschman, A.O. (1970). Exit, Voice, and Loyalty: Responses to Decline in Firms, Organizations, and States. Cambridge, MA: Harvard University Press.

Janis, I.L. (1982). Groupthink: Psychological studies of policy decisions and fiascoes. Boston: Houghton Mifflin.

Jones, D., Jussila, I. \& Kalmi, P. (2016). The Determinants of Membership in Cooperative Banks: Common Bond versus Private Gain, Annals of Public and Cooperative Economics, June 2016.

Jones, D. \& Kalmi, P. (2015). Membership and Performance in Finnish Financial Cooperatives: A New View of Cooperatives? Review of Social Economy, 73(3): 288-309.

Jovanović, T., Arnold, C. \& Voigt, K. (2017). Cooperative banks in need of transition: The influence of Basel III on the business model of German cooperative credit institutions, Journal of Co-operative Organization and Management, forthcoming.

Kelsen, H. (1920). Vom Wesen und Wert der Demokratie. Tübingen: Mohr.

Klingelhofer, J. (2010). Models of Electoral Competition: Three Essays in Political Economics. Stockholm University (Dept. of Economics): Doctoral Dissertation.

Krätke, M.R. (2008). On Economic Democracy, Transform! European Journal for Alternative Thinking and Political Dialogue, 2: 83-92. 
Kruger, J. \& Dunning, D. (1999). Unskilled and Unaware of It: How Difficulties in Recognizing One's Own Incompetence Lead to Inflated Self-Assessment, Journal of Personality and Social Psychology, 77(6): 1121-1134.

Leck, J.D. \& Saunders, D.M. (1992). Hirschman's loyalty: Attitude or behavior? Employee Responsibilities and Rights Journal, 5(3): 219-230.

Malleson, T. (2014). Economic democracy in the $21^{\text {st }}$ Century, openDemocracy, 15 August.

Manin, B. (1987). On Legitimacy and Political Deliberation, Political Theory, 3(15): 338-368.

Michels, R. (1910). La democrazia e la legge ferrea dell'oligarchia: saggio sociologico. Roma: Manuzio.

Mill, J. S. (2011 [1861]). Utilitarianism. London: Broadview.

Montesquieu, C.L. (1748). De l'esprit des loix. Amsterdam: Chatelain.

Mouffe, C. (2000). The Democratic Paradox. London: Verso.

Nagel, M. (2010). A Mathematical Model of Democratic Elections, Current Research Journal of Social Sciences, 2(4): 255-261.

Oliver Wyman (2014). Organizing for Effectiveness and Growth in Cooperative Financial Services, Report for the International Summit on Cooperatives, Quebec.

Osterloh, M., Frey, B.S. \& Zeitoun, H. (2011). Corporate Governance as an Institution to Overcome Social Dilemmas. In: A. Brink (Ed.), Corporate Governance and Business Ethics. Heidelberg: Springer.

Paredes-Frigolett, H., Nachar-Calderón, P. \& Marcuello, C. (2016). Modeling the governance of cooperative firms, Computational and Mathematical Organization Theory, 23(1): 122-166.

Rousseau, J.J. (1762). Du contrat social ou principes du droit politique. Amsterdam: Marc Michel Rey.

Sarcinelli, M. (1997). Bank Governance: Models and Reality, BNL Quarterly Review, March (Special Issue), 249-279.

Sartori, G. (2008). La democrazia in trenta lezioni. Milano: Mondadori.

Stefancic, M. (2015). Corporate Governance and Bank Regulation: Evidence from the Italian Cooperative Banking System. University of Ljubljana (Faculty of Economics): Doctoral Dissertation.

The Economist (2015). Not so popolari: Reform of Italy's biggest cooperative banks will help sector to consolidate. 23 January 2015.

Usher, D. (1981). The economic prerequisites to democracy. New York: Columbia University Press.

Williamson, O.E. (1986). The Economic institutions of Capitalism. Firms, markets, relational contracting. New York: Free press.

Withey, M.J. \& Cooper, W.H. (1989). Predicting Exit, Voice, Loyalty, and Neglect, Administrative Science Quarterly, 34(4): 521-539. 